\title{
Anti-inflammation Activity of Ageratum Conyzoides Leaf Ethanol Extract on Rattus Norvegicus
}

\author{
Maylani Permata Saputri*1, Riani Utami' ${ }^{2}$, Jasmine Fadila ${ }^{3}$, Santi Nur Handayani ${ }^{1}$ \\ 1Jurusan Kimia, Fakultas Matematika dan Ilmu Pengetahuan Alam, Universitas Jenderal \\ Soedirman \\ 2Jurusan Matematika Fakultas Matematika dan Ilmu Pengetahuan Alam, Universitas \\ Jenderal Soedirman \\ 3Jurusan Fisika Fakultas Matematika dan Ilmu Pengetahuan Alam, Universitas Jenderal \\ Soedirman
}

*E-mail: maylani.saputri@mhs.unsoed.ac.id

\begin{abstract}
Abstrak
Bandotan (Ageratum conyzoides L) merupakan tanaman yang mengandung senyawa metabolit sekunder berupa flavonoid dan alkaloid yang diduga mempunyai efek anti-inflamasi. Tujuan penelitian adalah mengetahui aktivitas anti-inflamasi ekstrak etanol daun $A$. conyzoides pada tikus yang diinduksi karagenan. Tahapan penelitian adalah maserasi daun A. conyzoides dalam pelarut etanol, uji fitokimia, dan uji aktivitas anti-inflamasi. Uji aktivitas anti-inflamasi dilakukan terhadap 25 tikus putih (Rattus norvegicus L.) jantan yang terbagi menjadi lima kelompok perlakuan yaitu kontrol (-) larutan CMC 0,5\%, kontrol (+) natrium diklofenak, dan pemberian ekstrak dengan dosis 30, 200 dan $448 \mathrm{mg} / \mathrm{kgBB}$. Parameter yang diamati yaitu volume kaki tikus setelah diinduksi $0,1 \mathrm{~mL}$ karagenan $1 \%$ selama 300 menit diukur dengan pletismometer. Hasil uji anti-inflamasi menunjukkan bahwa ekstrak etanol daun $A$. conyzoides dengan dosis 30 , 200 dan $448 \mathrm{mg} / \mathrm{kgBB}$ memiliki aktivitas anti-inflamasi dengan persen daya anti-inflamasi masing-masing sebesar 10,43; 21,67; dan 30,34 \%. Dosis $448 \mathrm{mg} / \mathrm{kgBB}$ menunjukkan tidak ada perbedaan signifikan dengan kontrol (+) pada uji ANOVA. Hasil penelitian menunjukkan ekstrak etanol daun $A$. conyzoides memiliki aktivitas anti-inflamasi.
\end{abstract}

Kata kunci: Daun A. conyzoides; Karagenan; Anti-inflamasi.

\begin{abstract}
Bandotan (Ageratum conyzoides) is a plant that contains secondary metabolites in the form of flavonoids and alkaloids which are thought to have anti-inflammatory activity. The aim of this research was to determine the anti-inflammatory activity of $A$. conyzoides leaves extract in carrageenan-induced mice. The stages of the study were maceration of A. conyzoides leaves in ethanol solvent, phytochemical test, and anti-inflammatory activity test. Anti-inflammatory activity test was carried out on 25 male white rats (Rattus norvegicus) which were divided into five treatment groups namely negative controls were given a $0.5 \%$ CMC solution, positive controls were
\end{abstract}


given diclofenac sodium, and administration of extracts with a dose of 30,200 and $448 \mathrm{mg} / \mathrm{kgBW}$. The parameters observed were mouse foot volume after $0.1 \mathrm{~mL}$ of carrageenan $1 \%$ induced for 300 minutes was measured with a pletismometer. Anti-inflammatory test results showed that the ethanol extract of A. conyzoides leaves at doses of 30, 200 and $448 \mathrm{mg} / \mathrm{kgBW}$ had antiinflammatory activity with percent anti-inflammatory of 10.43; 21.67; and 30.34\%. Dose 448 $\mathrm{mg} / \mathrm{kgBW}$ showed no significant difference with positive control in the ANOVA test. In conclusion, the ethanol extract of A. conyzoides leaves has anti-inflammatory activity.

Keywords: A. conyzoides leaf, Anti-inflammatory, Carrageenan.

\section{Pendahuluan}

Respon tubuh akibat adanya kerusakan jaringan atau infeksi disebut inflamasi. System kekebalan tubuh manusia akan berusaha menyingkirkan materi-materi yang membahayakan tubuh serta melakukan persiapan untuk perbaikan saat terjadi kerusakan jaringan(Sherwood, 2001). warna kemerahan pada kulit, bengkak, panas, serta nyeri merupakan indikasi dari inflamasi (Corwin, 2008).

Banyak jenis obat anti-inflamasi yang digunakan untuk meredakan inflamasi diantaranya obat anti inflamasi steroid dan non-steroid. Obat-obatan tersebut merupakan obat sintetik yang ternyata memiliki efek samping berbahaya pada saluran cerna dalam jangka waktu panjang (Lelo \& Hidayat, 2004). Karena bahaya dalam penggunaan obat anti-inflamasi sintetik cukup serius, maka pencarian senyawa yang lebih aman menjadi penting untuk dilakukan. Masyarakat Indonesia masih banyak yang menyukai pengobatan tradisional dengan menggunakan tanaman berkhasiat karena dianggap lebih aman serta mudah dijangkau (Umar, 2011). Tanaman yang berkhasiat yang berpotensi dijadikan bahan obat adalah bandotan (Ageratum conyzoides L.)

A. conyzoides Linn (bandotan) merupakan tumbuhan yang banyak dijumpai di negara beriklim tropis termasuk Indonesia. A. conyzoides Linn masuk dalam golongan famili Asteraceae dan suku Eupatorieace. Senyawa-senyawa metabolit sekunder pada daun $A$. conyzoides yaitu flavanoid, alkaloid (Handayani, 2019),

saponin dan minyak atsiri (Ming,1999). Kandungan flavanoid pada daun bandotan memiliki aktivitas antiinflamasi, sehingga tumbuhan sejenis gulma ini dapat di manfaatkan sebagai antiinflamasi. Flavonoid menghambat biosintesis prostaglandin, dengan menghambat enzim COX/siklooksigenase. Flavonoid memiliki aktivitas anti-inflamasi dikarenakan flavonoid dapat menghambatan siklooksigenase atau lipooksigenase dan menghambat akumulasi leukosit di daerah sehingga dapat menjadi anti-inflamasi (Narande, 2013).

Penelitian ini penting dilakukan agar mengetahui aktivitas anti-inflamasi dari daun $A$. conyzoides. potensi anti-inflamasi dari daun $A$. conyzoides selanjutnya dapat dijadikan referensi dan kajian lebih lanjut tentang senyawa untuk obat anti-inflamasi dari isolasi bahan alam, dan menghindari penggunaan senyawa sintesis untuk mengurangi resiko efek jangka panjang.

\section{Metode Penelitian}

Alat dan Bahan

Alat dan bahan yang digunakan adalah neraca analitik, gelas ukur (pyrex $100 \mathrm{ml}$ ), gelas beker (pyrex $1 \mathrm{~L}$ ), penangas, rotary evaporator, labu ukur (pyrex $10 \mathrm{ml}$ ), pipet volume(pyrex $10 \mathrm{ml}$ ), jarum injeksi, stopwatch, pletismometer, batang pengaduk, tabung reaksi, daun Ageratum conyzoides L, bahan kimia analytical grade berupa etanol $96 \%$, akuades, asam sulfat $2 \mathrm{~N}$, pereaksi Dragendorff, pereaksi Meyer, pereaksi 
Wagner, serbuk magnesium, amil alkohol, tikus putih (Rattus norvegicus L), CMC 0,5\%, natrium diklofenak dan karagenan.

Prosedur Kerja

\section{Pembuatan Ekstrak}

Pembuatan ekstrak didahului dengan pengumpuan bahan berupa daun $A$. conyzoides yang masih segar. Daun $A$. conyzoides yang masih segar kemudian dikeringkan dengan cara diangin-anginkan, setelah kering, daun dihaluskan menjadi serbuk. Serbuk daun A. conyzoides sebanyak 100 gram kemudian dimaserasi (direndam dalam gelas beker tertutup) dengan $1 \mathrm{~L}$ etanol 96\% sebagai selama 1x24 jam. Hasil maserasi kemudian disaring dan fitratnya kemudian di evaporasi dengan rotatory evaporator, sehingga didapatkan ektrak kasar.

\section{Uji Fitokimia}

-Uji Flavonoid

0,1 g Ekstrak etanol daun $A$. conyzoides di tabung reaksi ditambahkan 0,1 mg serbuk $\mathrm{Mg}, 0,4 \mathrm{~mL} \mathrm{C}_{5} \mathrm{H}_{12} \mathrm{O}$ dan $4 \mathrm{~mL}$ alcohol lalu dikocok. Reaksi positif apabila menghasilkan warna merah (Harborne, 1987).

-Uji Alkaloid

Ekstrak etanol daun $A$. conyzoides sebanyak $0,1 \mathrm{~g}$ dilarutkan dengan $\mathrm{H}_{2} \mathrm{SO}_{4} 2 \mathrm{~N}$ beberapa tetes. Diuji terhadap pereaksi Dragendorff, Meyer, dan Wagner. Hasil positif apabila terbentuk endapan merah jingga, putih, dan cokelat pada pereaksi Dragendorff, Meyer, dan Wagner (Harborne, 1987).

-Uji Saponin

$0.1 \mathrm{~g}$ Ekstrak etanol daun $A$. conyzoides ditambah $10 \mathrm{~mL}$ akuades dalam tabung reaksi, lalu dikocok 30 detik, reaksi positif jika terbentuk larutan berbuih mantap (Marliana et. al., 2005).

Uji Anti-inflamasi

Uji anti-inflamasi dilakukan terhadap 25 tikus putih (Rattus norvegicus L.) jantan yang terbagi atas lima kelompok perlakuan. Setiap kelompok terdiri dari lima tikus sebagai bentuk pengulangan. Penelitian ini menggunakan metode winter termodifikasi (Turner, 1965). Pembengkakan buatan dilakukan dengan cara menginjeksikan karagenan $1 \%$ sebanyak $0,1 \mathrm{~mL}$ pada kaki tikus secara subplantar menggunakan jarum suntik. Perlakuan tiap kelompok adalah:

- Kelompok 1 = Kontrol (-) larutan CMC $0.5 \%$

- Kelompok 2 = Kontrol (+) larutan $\mathrm{Na}-$ Diklofenak $20 \mathrm{mg} / \mathrm{KgBB}$

- Kelompok 3 = Ekstrak 30 mg/KgBB

- Kelompok $4=$ Ekstrak $200 \mathrm{mg} / \mathrm{KgBB}$

- Kelompok 5 = Ekstrak 448 mg/KgBB Sebelum diberi perlakuan, volume kaki tikus diukur, ditandai menggunakan spidol. Kemudian diinjeksikan karagenan 1\% sebanyak 0,1 mL secara subplantar pada telapak kaki tikus lalu diukur volumenya menggunakan plestimometer dengan dicelupkan hingga tanda batas. Hal tersebut dilakukan terhadap seluruh tikus, kemudian pengukuran kaki tikus dilakukan setiap 30 menit hingga menit ke 300. Lalu, persentase edema diperoleh dengan rumus:

Presentase radang $=\frac{\left(U_{t}-U_{0}\right)}{U_{0}} \times 100 \%$ Keterangan:

- $\mathrm{U}_{\mathrm{t}}=$ volum pada waktu $\mathrm{t}$

- $\mathrm{U}_{\mathrm{o}}=$ volum sebelum injeksi karagenan (Mansjoer, 1997)

Kurva persentase radang terhadap waktu dapat dibuat, lalu persentase AUC dihitung (Area Under Curve/luas daerah di bawah kurva) dari menit 0-300 tiap spesies dihitung dengan rumus:

$A U C_{t n-1}^{t n}=\frac{V t_{n-1}+V t_{n}}{2}\left(t_{n}-t_{n-1}\right)$

Keterangan :

- $\mathrm{Vt}_{\mathrm{n}-1}$ :rata- rata volum edema pada $\mathrm{t}_{\mathrm{n}-}$ 1

- $V t_{n}$ : rata-rata volum edema pada $t_{n}$ (Sari, 2017)

Nilai presentase daya anti-inflamasi (penghambatan volum edema) dapat diperoleh dari rumus: 
$\% \mathrm{DAI}=\frac{A U C_{k}-A U C_{p}}{A U C_{k}} \times 100 \%$

Keterangan :

- $\mathrm{AUC}_{\mathrm{k}}$ : AUC kurva volum edema ratarata terhadap waktu pada kontrol (-)

- $\mathrm{AUC}_{\mathrm{p}}$ : AUC kurva volum edema ratarata terhadap waktu pada kelompok perlakuan tiap spesies.

\section{Hasil dan Pembahasan}

Ekstrak pekat yang diperoleh dari hasil maserasi selama 1x24 jam sebanyak 7,31 gram. Ekstrak tersebut kemudian dilakukan uji fitokimia untuk mengetahui adanya kandungan flavonoid, alkaloid, dan saponin. Tabel 1 menunjukkan hasil uji fitokimia.

Tabel 1. Hasil uji fitokimia ekstrak etanol daun A. conyzoides

\begin{tabular}{cllc}
\hline Uji & Pereaksi & \multicolumn{1}{c}{ Hasil } & $\begin{array}{c}\text { Keter } \\
\text { angan }\end{array}$ \\
\hline Alkaloid & Meyer & $\begin{array}{l}\text { Endapan } \\
\text { putih }\end{array}$ & + \\
& Wagner & $\begin{array}{l}\text { Endapan } \\
\text { cokelat }\end{array}$ & + \\
\hline & $\begin{array}{l}\text { Dragendor } \\
\text { f }\end{array}$ & $\begin{array}{l}\text { Endapan } \\
\text { merah } \\
\text { jingga }\end{array}$ & + \\
\hline Flavonoid & $\begin{array}{l}\text { HCl } \\
\text { pekat+Mg+ } \\
\text { amil } \\
\text { alkohol }\end{array}$ & Merah & + \\
& & \\
\hline Saponin & Akuades & Berbuih & + \\
\hline
\end{tabular}

Tabel 1 menunjukkan bahwa ekstrak etanol daun $A$. conyzoides yang diperoleh mengandung alkaloid, flavonoid dan saponin. Sesuai dengan penelitian yang dilakukan sebelumnya oleh Hidayati (2017). Senyawa metabolit sekunder yang terkandung diduga memiliki aktivitas anti-inflamasi.

Uji anti-inflamasi dilakukan dengan cara mengukur volume edema (pembengkakan) pada kaki tikus sebelum dan setelah injeksi selang waktu 30 menit selama 300 menit. Setelah itu, dilakukan perhitungan persentase edema terhadap waktu.

Gambar 1 menunjukan bahwa kurva tertinggi adalah kontrol negatif (CMC 0.5\%). Kelompok kontrol (-) volume radang yang dihasilkan lebih besar dibandingkan dengan kelompok yang lainnya. Tanda panah dalam kurva menunjukkan ekstrak etanol daun $A$. conyzoides memiliki daya menghambat inflamasi sedingga edema lebih kecil dari kontrol negatif. Kurva terendah tampak pada kurva kontrol positif (Na-diklorofenak), dan kurva dari variansi konsentrasi ekstrak $A$. conyzoides $30 \mathrm{mg} / \mathrm{kgBB}, 200 \mathrm{mg} / \mathrm{kgBB}, 448$ $\mathrm{mg} / \mathrm{kgBB}$ berada diantara kontrol (+) dan kontrol negatif. Hal ini mengindikasikan bahwa pemberian ekstrak $A$. conyzoides dapat mengurangi volume edema dan berpotensi sebagai obat anti-inflamasi.

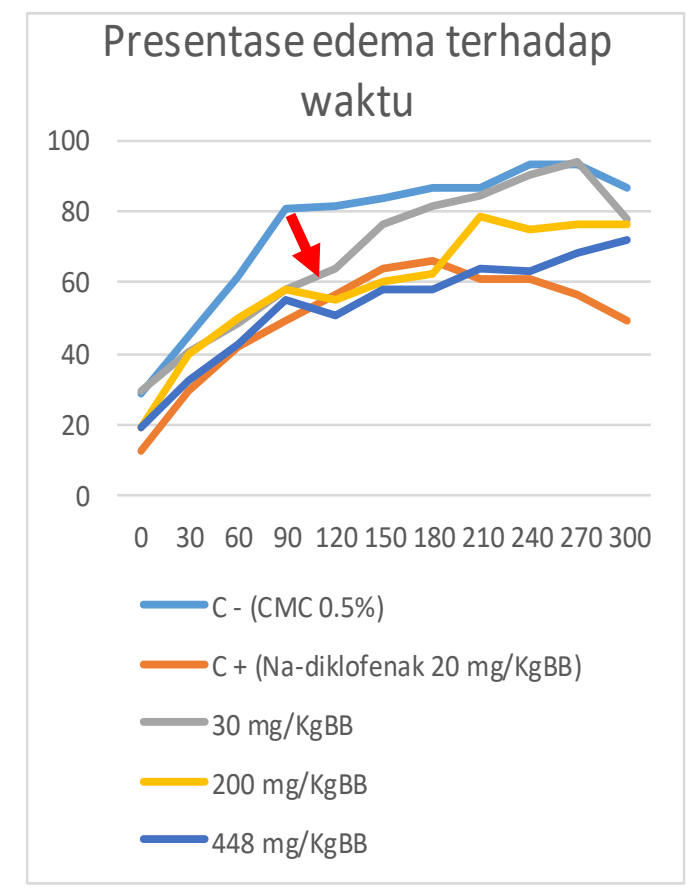

Gambar 1. Kurva Persentase Edema pada Kaki Tikus terhadap Waktu 
Tabel 2. Daya Anti-inflamasi dari berbagai Perlakuan

\begin{tabular}{cccc}
\hline No & Perlakuan & AUC & \%DAI \\
\hline 1 & Kontrol - & 23134,29 & - \\
\hline 2 & Kontrol + & 15487,50 & 33,5 \\
\hline 3 & $\begin{array}{c}\text { A. conyzoides } \\
\text { 30 mg/KgBB }\end{array}$ & 20719,64 & 10,43 \\
\hline 4 & A.conyzoides & 18120,24 & 21,68 \\
\hline 5 & A. conyzoides & 16115,24 & 30,34 \\
& 448 mg/KgBB \\
\hline & Daya anti-inflamasi merupakan
\end{tabular}

kemampuan zat untuk mengurangi edema yang ada pada kaki hewan uji setelah diinjeksi karagenan (Hidayati dkk, 2008). Nilai daya anti-inflamasi diperoleh dari perbandingan $A U C$ yang diberi ekstrak $A$. conyzoides dan kontrol (+) dengan AUC kontrol (-). Dari Tabel 2, diperoleh bahwa pada pemberian variansi dosis $30 \mathrm{mg} / \mathrm{kgBB}$, $200 \mathrm{mg} / \mathrm{kgBB}, 448 \mathrm{mg} / \mathrm{kgBB}$ diperoleh daya anti-inflamasi berturut-turut 10,43\%, $21,68 \%$, dan 30,34\%. Pada dosis 448 $\mathrm{mg} / \mathrm{kgBB}$ daya anti-inflamasi yang diperoleh hampir mendekati daya anti-inflamasi dari kontrol positif.

Berdasarkan hasil analisis statistik uji normal menggunakan SPSS dengan taraf signifikansi 95\%, diperoleh hasil bahwa nilai AUC berdistribusi normal dan berasal dari populasi yang sama. Hasil analisis dilanjutkan menggunakan uji ANOVA dan $L S D$ dengan tingkat kepercayaan $95 \%$ untuk membedakan antar kelompok. Hasil uji ANOVA tersebut menghasilkan bahwa adanya perbedaan yang signifikan antara ketiga perlakuan variansi konsentrasi ekstrak $A$. conyzoides dengan kontrol negatif (p-value $<0,05$ ), sementara jika dibandingkan dengan kontrol $(+)$ ketiga perlakuan pada pemberian konsentrasi ekstrak tidak ada perbedaaan yang signifikan ( $\mathrm{p}$-value $>0.05$ ) hal ini menunjukan bahwa $A$. conyzoides berpotensi menjadi obat anti-inflamasi.

Efek anti-inflamasi yang ditunjukkan ekstrak diduga karena adanya kandungan flavonoid (Hidayati dkk, 2008). Mekanisme anti-inflamasi senyawa flavonoid dengan menghambat aktivitas enzim COX (Nijveldt et. al., 2001 ; Robak \& Gryglewski ,1996). Penghambatan enzim COX/lipoooksigenase akan menyebabkan biosintesis eikosanoid dan leukotrien terganggu sehingga tidak terbentuk prostaglandin yang menyebabkan inflamasi (Mueller, 2005).

\section{Simpulan}

Ekstrak daun Ageratum conyzoides mempunyai aktivitas anti-inflamasi dengan persen daya anti-inflamasi pada dosis $30 \mathrm{mg} / \mathrm{kgBB}, \quad 200 \mathrm{mg} / \mathrm{kgBB}, \quad 448 \mathrm{mg} / \mathrm{kgBB}$ berturut-turut adalah 10,43\%, 21,68\%, dan 30,34\%. Hasi uji ANOVA dan dengan uji LSD dengan taraf signifikansi $95 \%$ menunjukan bahwa variansi konsentrasi tidak berbeda signifikan terhadap kontrol positif berupa Na-diklofenak. Hal ini menunjukan bahwa ekstrak A.conyzoides berpotensi menjadi obat anti-inflamasi.

\section{Ucapan Terima Kasih}

Terima kasih kepada Kemenristekdikti yang telah membiayai kegiatan Program Kreatifitas Mahasiswa 2018.

\section{Daftar Pustaka}

Arsyita Sari,2017, Uji Aktivitas Anti-inflamasi Ekstrak Etanol Rimpang Lengkuas (Alpinia galanga) Pada Tikus Putih Jantan Galur Wistar Yang Diinduksi Karagenan,Skripsi,Universitas Muhammadiyah Surakarta.

Corwin, E.J., (2008), Buku saku patofisiologi. EGC, Jakarta.

Hartanto, Puji., 2007, Prinsip Kerja Tanaman Obat Seluruh Dunia.Purwokerto: Penerbit Litbang Team An Nahl: Purwokerto.

Hidayati, 2008, Kandungan kimia dan uji anti-inflamasi ekstrak Lantana camara. Bioteknologi, 5 (1): 10-17. 
Lelo A. dan Hidayat, 2004, NSAIDS: Friend or Foe. Makassar: Journal of the Indonesia Dental Association.

Mansyur, S., 1997, Efek Anti Radang Minyak Atsiri Temu Putih (Curcuma zedoria Rosc.) Terhadap Edema Buatan Pada Tikus Putih Jantan Galur Wistar, Majalah Farmasi Indonesia 8: 35-41.

Ming LC, 1999, Ageratum conyzoides: A trapical source of medicinal and agricultural product. J.Janick, ASHS Press, Alexandria, VA.

Mueller, J., 2005, Bioflavonoids: Natural Relief for Allergies and Asthma, www.worldwidehealthcenter.net/a rticles336.html

Narande J. M., Anne W., dan Adithya Y., 2013, Uji Efek Antiinflamsi Ekstrak etanol Daun Suji (Dracaena angustifolia Roxb) Terhadap Edema Kaki TikusPutih Jantan Galur Wistar. Pharmacon, 2(3): 14-18.

Nijveldt, R.J, van Nood E, Van Hoon DEC. Boelens PG, van Norren $K$, van Leeuwen PAM, 2001, Flavonoids: a review of probable mechanisms of action and potential applications, Am J Clin Nutr, 74: 418-425.

Handayani S.N, Maylani P.S, Riani,U., Jasmine F., 2019, Antibacterial Activity Test Ethanol Extract Leaf $A$. conyzoides Linn against Staphylococcus aureus and Escherichia coli Bacteria, International Journal of ChemTech Research, 12(05): 258-262.

Hidayati A.S, Harjono, 2017, Uji Aktivitas Antibakteri Krim Ekstrak Daun Babadotan (Ageratum conyzoides. L) dalam Pelarut Etanol, Jurnal MIPA, 40(01): 33-38.

Rania F, Ahmed, 2016, Resveratrol In Combination Of Ibuprofen Against Acute Carragenan-Induced Inflammation And Hepatic Insult: Rectification of Adenylate Energy Charge (AEC), Antiapoptotic, Cell Proliferation And DNA Preservation Potentials. International Journal of
Pharmtech Research, 9(10): 511532.

Robak, J. and Gryglewski R.J, 1996, Bioactivity of flavonoids, Polish Journal of Pharmacology 48(6): 555-564.

Sherwood, Lauralee. (2001). Fisiologi Manusia: Dari Sel ke Sistem. Edisi 2, EGC, Jakarta.

Turner, Robert. A., 1965, Screening Methods in Pharmacology, Academic Press, New York.

Umar, Anandini Nindya Lestari \& Subakir, Subakir \& Suhardjono, Suhardjono., 2011, Perbandingan Ekstrak Daun Kemangi (Ocimum basilicum L.) dengan Ketokonazol 2\% dalam Menghambat Pertumbuhan Candida sp. pada Kandidiasis Vulvovaginalis, Thesis, Fakultas Kedokteran Universitas Diponegoro, Semarang. 